\title{
Characterization of photochromogenic Mycobacterium spp. from Chesapeake Bay striped bass Morone saxatilis
}

\author{
D. T. Gauthier ${ }^{1, *}$, A. M. Helenthal ${ }^{1}$, M. W. Rhodes ${ }^{2}$, W. K. Vogelbein ${ }^{2}$, H. I. Kator ${ }^{2}$ \\ ${ }^{1}$ Department of Biological Sciences, Old Dominion University, Norfolk, Virginia 23529, USA \\ ${ }^{2}$ Virginia Institute of Marine Science, The College of William and Mary, \\ Department of Environmental and Aquatic Animal Health, Gloucester Point, Virginia 23062, USA
}

\begin{abstract}
A large diversity of Mycobacterium spp. has been isolated from striped bass Morone saxatilis in Chesapeake Bay, USA. The new species $M$. shottsii and $M$. pseudoshottsii are the dominant isolates, while the classical fish pathogen $M$. marinum is found much less frequently. $M$. fortuitum and M. chelonae, other Mycobacterium spp. known to commonly infect fishes, have not yet been aseptically isolated from striped bass within Chesapeake Bay. While M. pseudoshottsii and $M$. shottsii have been phenotypically and genotypically characterized, other less common mycobacterial isolates have not. In the present study, we describe 17 photochromogenic isolates from Chesapeake Bay striped bass using phenotypic characterization and multilocus sequencing of 16S rRNA, hsp65 and $r p o B$ genes. Genetic characterization reveals that these isolates are related to widely divergent portions of the mycobacterial phylogeny; however, some interesting trends are observed, such as a majority of isolates (10/17) belonging to the $M$. simiae-related grouping. Five additional isolates were assigned to the slow-growing mycobacteria (including 2 identified as $M$. marinum), while 2 are clearly shown to belong genetically to the fast-growing mycobacteria.
\end{abstract}

KEY WORDS: Mycobacterium spp. ' Photochromogenic · Striped bass · Morone saxatilis · Chesapeake Bay · Multilocus sequencing

Resale or republication not permitted without written consent of the publisher

\section{INTRODUCTION}

The genus Mycobacterium currently contains 148 recognized species, of which 61 attained named status within the last decade (Euzéby 1997). The previously unrecognized diversity of this group is further attested to by the large and growing number of sequences on public databases (e.g. GenBank) that group, phylogenetically, with the mycobacteria, but which differ from recognized species and strains. Many newly described species are associated with human infections and clinical outbreaks (e.g. Schinsky et al. 2004, Cloud et al. 2006), while others are derived from a range of sources, including environmental samples (e.g. Torkko et al. 2000, 2002, Hennessee et al. 2009) and nonhuman vertebrates (e.g. Shojaei et al. 2000, Cousins et al. 2003). Aquatic poikilotherms in particular have been a productive source of novel Mycobacterium spp., including $M$. montefiorense from moray eels Gymnothorax funebris (Levi et al. 2003), M. shottsii and $M$. pseudoshottsii from striped bass Morone saxatilis (Rhodes et al. 2003, 2005), M. stomatepiae from the cichlid Stomatepia mariae (Pourahmad et al. 2008), and $M$. salmoniphilum from salmonids, a revived species name which was recently differentiated from $M$. chelonae (Whipps et al. 2007).

Striped bass in Chesapeake Bay, USA, have been experiencing a high prevalence of mycobacteriosis since the initial description of this disease in these fish in 1997 (see Gauthier \& Rhodes 2009). The striped bass is a commercially and recreationally important species as well as a keystone predator in the Chesapeake Bay 
ecosystem, so that this disease creates concern for the continued health of the population. The 3 species of Mycobacterium traditionally associated with infections in fishes are M. marinum, M. chelonae and M. fortuitum (Gauthier \& Rhodes 2009), and reports continue to implicate these species in fish disease worldwide. It was therefore surprising when bacteriological surveys of Chesapeake Bay striped bass conducted from 1997 to 2001 indicated that M. marinum comprised only about $3 \%$ of Chesapeake Bay striped bass isolates, and neither $M$. chelonae nor $M$. fortuitum was detected (Rhodes et al. 2004). Since this first report, $M$. chelonae has been isolated from only a single striped bass in Delaware Bay (Ottinger et al. 2007), and M. fortuitum has not yet been isolated from internal tissues of this fish. Instead, a suite of biochemically diverse, primarily slow-growing mycobacteria has been isolated, including $M$. shottsii and M. pseudoshottsii (Rhodes et al. 2001, 2003, 2004, 2005), which are related to M. marinum and $M$. ulcerans. M. pseudoshottsii and $M$. shottsii appear to be the dominant isolates, although a phenotypic grouping of non-pigmented, slow-growing mycobacteria similar to $M$. triplex and $M$. interjectum are also numerically relevant (Rhodes et al. 2004). More recent work using fatty acid methyl ester (FAME) analysis and DNA sequence data on mycobacterial isolates recovered from Chesapeake Bay striped bass and other fishes has further demonstrated the large diversity of Mycobacterium species and/or strains capable of infecting fishes in this ecosystem (Stine et al. 2010). It therefore appears that infections with Mycobacterium spp. in Chesapeake Bay striped bass represent a situation unique to those previously reported for wild fishes elsewhere, with a large diversity of newly described and undescribed slow-growing species involved in infections, and potentially, disease.

To date, Mycobacterium pseudoshottsii and $M$. shottsii have been the only mycobacteria infecting striped bass to have had significant genotypic characterization in addition to phenotypic description. The goal of the present study was to elucidate the molecular phylogeny of an additional 17 Mycobacterium spp. isolated from Chesapeake Bay striped bass, and to place them in context with other deposited sequences from mycobacteria from the same host and region. We used multilocus sequencing to improve the robustness of phylogenetic positioning for the 17 isolates described in the present study, and 16S rRNA gene data for other comparisons. We also provide phenotypic characterization of the 17 isolates, as well as basic data on the fish from which they were isolated.

The majority of isolates (16/17) in the present study are classified as Type I according to the scheme of Runyon (1959), in that they produce pigment upon exposure to light and take $>7 \mathrm{~d}$ to form visible colonies on agar media. One isolate (324-016) would be classified as Runyon Type IV based on its growth characteristics (visible colonies in $<7 \mathrm{~d}$ ), but is photochromogenic, unlike most mycobacteria in this group. The Runyon classification is entirely phenotypic and therefore produces artificial groupings of distantly-related mycobacteria, as well as splitting closely related bacteria between types. For example, the unpigmented $M$. shottsii (Type III), is grouped separately from the genetically closely related photochromogenic M. pseudoshottsii (Type I). However, this scheme is still in use today, and it provides a convenient descriptive grouping tool to divide the large panel of isolates that have been recovered from striped bass in Chesapeake Bay. Multilocus sequencing of slow-growing scotopigmented (Type II) and non-pigmented (Type III) Mycobacterium spp. isolated from striped bass is ongoing and will be dealt with in a future manuscript.

As with other bacterial genera, the 16S rRNA gene is useful for phylogenetic identification of the mycobacteria (Rogall et al. 1990); however, the high degree of conservation of this gene within Mycobacterium (>94\%) presents limitations for differentiation of species which may be markedly different in phenotype. For example, M. gastri and M. kansasii are $100 \%$ similar in 16S rRNA gene sequence, and M. marinum strain $\mathrm{M}$ and $M$. ulcerans strain Agy99 differ by only $5 \mathrm{bp}$ over the full $1542 \mathrm{bp}$ length of the gene. Due to the occasionally low discriminatory power of the $16 \mathrm{~S}$ rRNA gene for this genus, sequence data from other housekeeping genes have been used for phylogenetic and diagnostic purposes, including erp (de MendoncaLima et al. 2001), gyrB (Kasai et al. 2000), hsp65 (Telenti et al. 1993), internal transcribed spacer (ITS) (Roth et al. 1998), recA (Blackwood et al. 2000), rpoB (Kim et al. 1999, 2004), and sod (Zolg \& Philippi-Schulz 1994, Devulder et al. 2005). The utility of multilocus sequencing (MLS) for robust phylogenetic differentiation of the mycobacteria has been demonstrated (Devulder et al. 2005), and alternative loci (e.g. crtB, fbpA, adk, ppk, aroE and $g l c B$ ) have been successfully used for generating phylogenies within closely related complexes, such as the M. marinum grouping (Stinear et al. 2000, Yip et al. 2007).

Our choice of loci for MLS in the present study was primarily based on availability of sequence in public databases for comparative purposes, as well as demonstrated phylogenetic discriminatory power of loci by previous authors. We used a portion of the 16S rRNA gene, including variable regions $A$ and $B$, to which considerable attention has been paid in previous studies of mycobacterial phylogeny (e.g. Rogall et al. 1990, Tortoli 2003). Region A includes helices 8 to 11 of the folded 16S rRNA molecule, and a cytosine insertion in this region is characteristic of thermotolerant fast- 
growing mycobacteria (Tortoli 2003). Region B includes helix 18 of the 16S rRNA molecule, and insertions within this region are, with exceptions, characteristic of slow-growing mycobacteria, while the presumably ancestral short helix is characteristic of fast growers (Tortoli 2003). The second locus used in the present study is the so-called 'Telenti fragment' of the mycobacterial hsp65 gene which has been used extensively in previous studies for both sequencing and restriction fragment polymorphism analysis (Telenti et al. 1993). The third and final locus used in the present study is a fragment of the $r p o B$ gene shown previously by Kim et al. (1999) to have discriminatory power among the mycobacteria. For reference, the first 2 loci in the present study are consistent in terms of sequence position with those reported by Devulder et al. (2005). The rроB fragment here is consistent with that of Kim et al. (1999) and includes $301 \mathrm{bp}$ found at the 5 ' end of the fragment reported by Devulder et al. (2005). In order to improve phylogenetic placement of photochromogenic isolates from Chesapeake Bay striped bass within known Mycobacterium spp., we compared artificial concatemers of the 3 sequenced fragments described above and compared them with homologous concatemers generated from a deposited sequence.

\section{MATERIALS AND METHODS}

Fish collections and bacterial isolation. Striped bass Morone saxatilis from the Rappahannock River, Virginia, were collected via pound net as part of ongoing tag-recapture studies to examine the prevalence of, and mortality related to, mycobacteriosis. Striped bass were collected from the mainstem of Chesapeake Bay via otter trawl using the Chesapeake Bay Multispecies Monitoring and Assessment Program (ChesMMAP; see Gauthier et al. 2008a). Fish were placed on ice immediately and necropsy was performed within $24 \mathrm{~h}$ after collection. Bacterial isolation and phenotypic characterization were as described in previous work (Rhodes et al. 2004, Gauthier et al. 2008b). Briefly, 0.1 to $0.5 \mathrm{~g}$ of spleen was homogenized using a Tenbroek tissue grinder, and dilutions were made in Butterfield's buffer $+0.05 \%$ Tween-80. Dilutions were plated (0.2 ml per plate) on Middlebrook 7H10 agar with oleic albumin dextrose catalase (OADC) enrichment (MDA), and plates were incubated at room temperature $(23 \pm$ $1^{\circ} \mathrm{C}$ ) for up to $3 \mathrm{mo}$. All isolations were made from aseptically collected spleen samples. Individual colonies were picked from initial isolation plates and grown in Middlebrook $7 \mathrm{H} 9$ broth with OADC enrichment and $0.05 \%$ Tween-80 (MDB) at room temperature until turbid. Broth cultures were restreaked on
MDA to ensure purity, regrown in MDB, and DNA was extracted from cell pellets after centrifugation. Phenotypic characterization of study isolates, including growth at room temperature, $30^{\circ} \mathrm{C}$ and $37^{\circ} \mathrm{C}$, is presented in Table 1.

Histology. Preparation of spleen samples for histological examination and enumeration of granulomas was performed as previously described (Gauthier et al. 2008a). Splenic area measurements were taken by photographing sections at $6.3 \times$ magnification on an Olympus SZX-ZB9 dissecting microscope equipped with a Nikon DXM1200 digital camera. Splenic area $\left(\mathrm{mm}^{2}\right)$ was calibrated and measured with MetaMorph software (Universal Imaging). Area measurements were taken on all sections examined for granulomas, excluding fish with no granulomas. The severity index (SI) was calculated as $\log _{10}$ (granulomas $\mathrm{mm}^{-2}+1$ ), and disease severity was assigned as follows: negative $(0)$ : $\mathrm{SI}=0$; minor (1): $0<\mathrm{SI} \leq 0.1$; moderate (2): $0.1<\mathrm{SI}$ $\leq 0.5$; severe (3): $\mathrm{SI}>0.5$.

Preparation of DNA and PCR. Turbid bacterial cultures were mechanically disrupted with $0.1 \mathrm{~mm}$ zirconium-silicon beads in a beadmill (FastPrep, Thermo Fisher). This was followed by column-based (QIAGEN DNeasy) or phenol-chloroform purification (Ausubel et al. 1999) of total genomic DNA. PCR was performed in a C1000 Thermal Cycler (Bio-Rad) in a $25 \mu \mathrm{l}$ final volume containing $1 \mu \mathrm{l}$ of extracted mycobacterial DNA template. Each reaction contained 1× Q-solution (QIAGEN), $0.2 \mathrm{mM}$ dNTPs, $1 \mu \mathrm{M}$ each of forward and reverse primer, $1 \times$ PCR buffer containing $1.5 \mathrm{mM}$ $\mathrm{MgCl}_{2}$ (QIAGEN), and $1.25 \mathrm{U}$ Taq polymerase (TopTaq, QIAGEN). PCR was performed as follows: initial denaturation of $3 \mathrm{~min}$ at $94^{\circ} \mathrm{C} ; 36$ cycles of denaturation at $94^{\circ} \mathrm{C}$ for $30 \mathrm{~s}$, annealing at $61^{\circ} \mathrm{C}(16 \mathrm{~S}$ rRNA gene), $55^{\circ} \mathrm{C}(h s p 65)$, or $58^{\circ} \mathrm{C}(r p o B)$ for $45 \mathrm{~s}$, and extension at $72^{\circ} \mathrm{C}$ for $60 \mathrm{~s}$; and a 7 min final extension at $72^{\circ} \mathrm{C}$. Primer pairs used for amplification of $16 \mathrm{~S}, \mathrm{hsp} 65$ and $r p o B$ were, respectively, M16seq-1F (5'-CTC AGG ACG AAC GCT GGC GG-3') and M16seq-1R (5'-ACT GCC CAG AGA CCC GCC TT-3'); Tb11 and Tb12 (Ringuet et al. 1999); and MF and MR (Kim et al. 1999). Expected product sizes for the 3 primer sets were 696 to $717 \mathrm{bp}$ for $16 \mathrm{~S}, 439 \mathrm{bp}$ for hsp65, and $342 \mathrm{bp}$ for гров. Amplified DNA was electrophoresed on a $2 \%$ agarose gel, stained with SybrSafe (Invitrogen), and imaged with $360 \mathrm{~nm}$ UV light.

Sequencing. PCR products were purified with ExoSAP-IT (USB Scientific) according to the manufacturer's directions. Direct sequencing was performed on PCR products bi-directionally using BigDye ${ }^{\circledR}$ Terminator v3.1 Cycle Sequencing Kit (Applied Biosystems) and the primers used for initial amplification. At least 2 separate PCR reactions were sequenced for each isolate. 
Table 1. Phenotypic characterization of photochromogenic Mycobacterium spp. isolated from Chesapeake Bay striped bass Morone saxatilis. Groupings are as discussed in the text. Relative growth at room temperature (RT), $30^{\circ} \mathrm{C}$ and $37^{\circ} \mathrm{C}$ (when growth was observed) is shown under 'Growth at temp. $\left({ }^{\circ} \mathrm{C}\right)^{\prime}$. Arylsulfatase activity is that observed on Day 3 and Day 14 . Catalase tests are for heat tolerance at $68^{\circ} \mathrm{C}$ and semiquantitative production (SQ). Pyrazinamidase activity is that observed on Day 4 and Day 7. ND: no data; \pm : variable to weak reaction

\begin{tabular}{|c|c|c|c|c|c|c|c|c|}
\hline $\begin{array}{l}\text { Isolate } \\
\text { name }\end{array}$ & $\begin{array}{l}\text { Growth at } \\
\text { temp. }\left({ }^{\circ} \mathrm{C}\right)\end{array}$ & $\begin{array}{l}\text { Aryl-sulfatase } \\
\text { Day 3/14 }\end{array}$ & $\begin{array}{l}\text { Catalase } \\
68^{\circ} \mathrm{C} / \mathrm{SQ}\end{array}$ & $\begin{array}{l}\text { Nitrate } \\
\text { reductase }\end{array}$ & $\begin{array}{c}\text { Pyrazin-amidase } \\
\text { Day } 4 / 7\end{array}$ & $\begin{array}{l}5 \% \mathrm{NaCl} \\
\text { tolerance }\end{array}$ & $\begin{array}{c}\text { Tween } \\
\text { hydrolysis }\end{array}$ & Urease \\
\hline \multicolumn{9}{|c|}{ M. simiae-related Group A } \\
\hline $324-844$ & $30>\mathrm{RT}$ & $-/+$ & $+/+$ & - & $-1-$ & - & \pm & + \\
\hline $324-569$ & $30 \geq \mathrm{RT}$ & $-/+$ & $+/+$ & - & $-/ \mathrm{ND}$ & ND & \pm & + \\
\hline $324-137$ & $30=\mathrm{RT}$ & $-/-$ & $+/+$ & + & $-/-$ & - & - & + \\
\hline $324-815$ & $30=\mathrm{RT}$ & $-/+$ & $+/+$ & - & $-1-$ & - & - & + \\
\hline $324-635$ & $30=\mathrm{RT}$ & $-/+$ & $+/+$ & - & $-/-$ & - & - & \pm \\
\hline $324-669$ & $30>\mathrm{RT}$ & $-/+$ & ND/ND & - & $-/-$ & ND & - & + \\
\hline \multicolumn{9}{|c|}{ M. simiae-related Group B } \\
\hline $164-251$ & $30=\mathrm{RT}$ & $-/+$ & $\pm / \pm$ & - & $-/-$ & - & - & - \\
\hline $324-575$ & $30=\mathrm{RT}$ & $-/-$ & $+/+$ & + & $-/-$ & - & - & + \\
\hline $324-692$ & $30>\mathrm{RT}$ & $-/-$ & $+/+$ & + & $-/ \pm$ & ND & - & + \\
\hline $324-953$ & $30=\mathrm{RT}$ & $+/+$ & $\mathrm{ND} /+$ & - & $-1-$ & - & - & + \\
\hline \multicolumn{9}{|c|}{ Fast-growing } \\
\hline $324-016$ & $30=\mathrm{RT}$ & $+/+$ & $\pm / \pm$ & - & $+/+$ & + & + & + \\
\hline $324-668$ & $30>\mathrm{RT}>37$ & $-/-$ & $-/-$ & + & $-/-$ & - & - & \pm \\
\hline \multicolumn{9}{|c|}{ M. marinum } \\
\hline $453-022$ & $30>\mathrm{RT}$ & $+/+$ & $-1-$ & - & $-/-$ & - & \pm & + \\
\hline $324-958$ & $30=\mathrm{RT}>37$ & $-/+$ & ND/- & - & $+/+$ & \pm & + & + \\
\hline \multicolumn{9}{|c|}{ Misc. slow-growing } \\
\hline $324-166$ & $30>\mathrm{RT}$ & $+/+$ & $-/-$ & - & $-/-$ & - & - & + \\
\hline $453-019$ & $30>\mathrm{RT}$ & $+/+$ & $\pm /-$ & - & $-/ \mathrm{ND}$ & - & - & - \\
\hline $324-648$ & $30=\mathrm{RT}$ & $\pm /+$ & $+/+$ & + & $-/-$ & - & - & + \\
\hline
\end{tabular}

Sequence analysis. Sequence editing and alignment, as well as BLAST searches and construction of phylogenetic trees, was performed with Geneious software (Biomatters; Drummond et al. 2010). Consensus sequences were generated from at least 6 total forward and reverse sequences, and including sequences from least 2 PCR reactions. 16S rRNA, hsp65 and rpoB gene sequences from Chesapeake Bay striped bass isolates were aligned and trimmed for primer sequences. Additionally, for consistency with previous literature, 16S rRNA gene sequences were trimmed to match position coverage with sequences deposited by Devulder et al. (2005). Sequences were then concatemerized in the order 16S rRNA-hsp65-rpoB and aligned with homologous concatemers generated from Mycobacterium spp. sequences from GenBank. In order to maintain continuity with previous work, all reference sequences (i.e. those not generated from Mycobacterium spp. isolates from Chesapeake Bay fishes) were those deposited by Devulder et al. (2005), with exceptions noted in Fig. 1. A final 1277 bp concatemer alignment was generated and used for phylogenetic placement of photochromogenic isolates from Chesapeake Bay striped bass (Fig. 1). Phylogenies based on individual genes were also constructed (not shown). The optimal model for construction of phylogenetic trees was determined for individual alignments with jModelTest (Posada 2008) under default settings and calculating log likelihoods for all available models. Model fit was compared with the $\triangle$ AIC method, and the best-fit model was used to construct the phylogenetic tree by maximum likelihood using the PHYML plugin for

Fig. 1. Mycobacterium spp. Maximum likelihood analysis of global phylogeny (GTR+I+G model, 4 substitution rates) including concatenated fragments of 16S rRNA, hsp65 and rpoB genes (1277 bp). Photochromogenic isolates from Chesapeake Bay striped bass Morone saxatilis are indicated in boldface. Other sequences are as described in Devulder et al. (2005), with the following exceptions: 16S rRNA gene sequences for $M$. agri (AY438067), M. hiberniae (AY438069), M. kommosense (AY438077) and M. lacus (AY438078); hsp65 sequences for M. agri (AY438080), M. bovis BCG (AY438082), M. hiberniae (AY438083), M. kommosense (AY438649) and M. lacus (AY438090); rpoB sequence for M. genavense (AF057467; Kim et al. 2004). Groupings (i.e. fastgrowing, slow-growing, M. simiae-related) are consistent with previous work (Rogall et al. 1990, Tortoli 2003). Bootstrap $(\mathrm{n}=500)$ proportions $>50 \%$ are presented at nodes. The scale bar is substitutions per site 


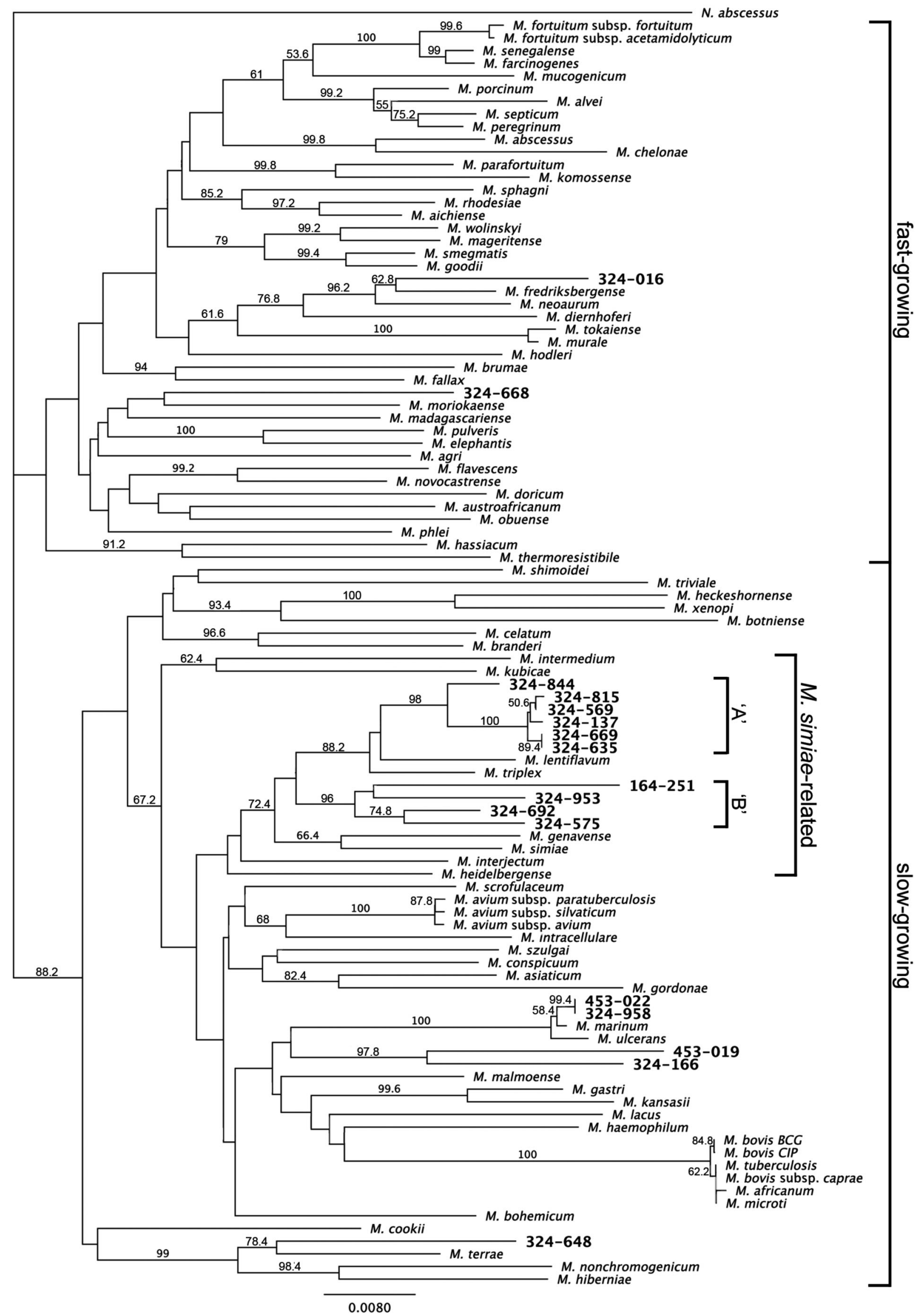




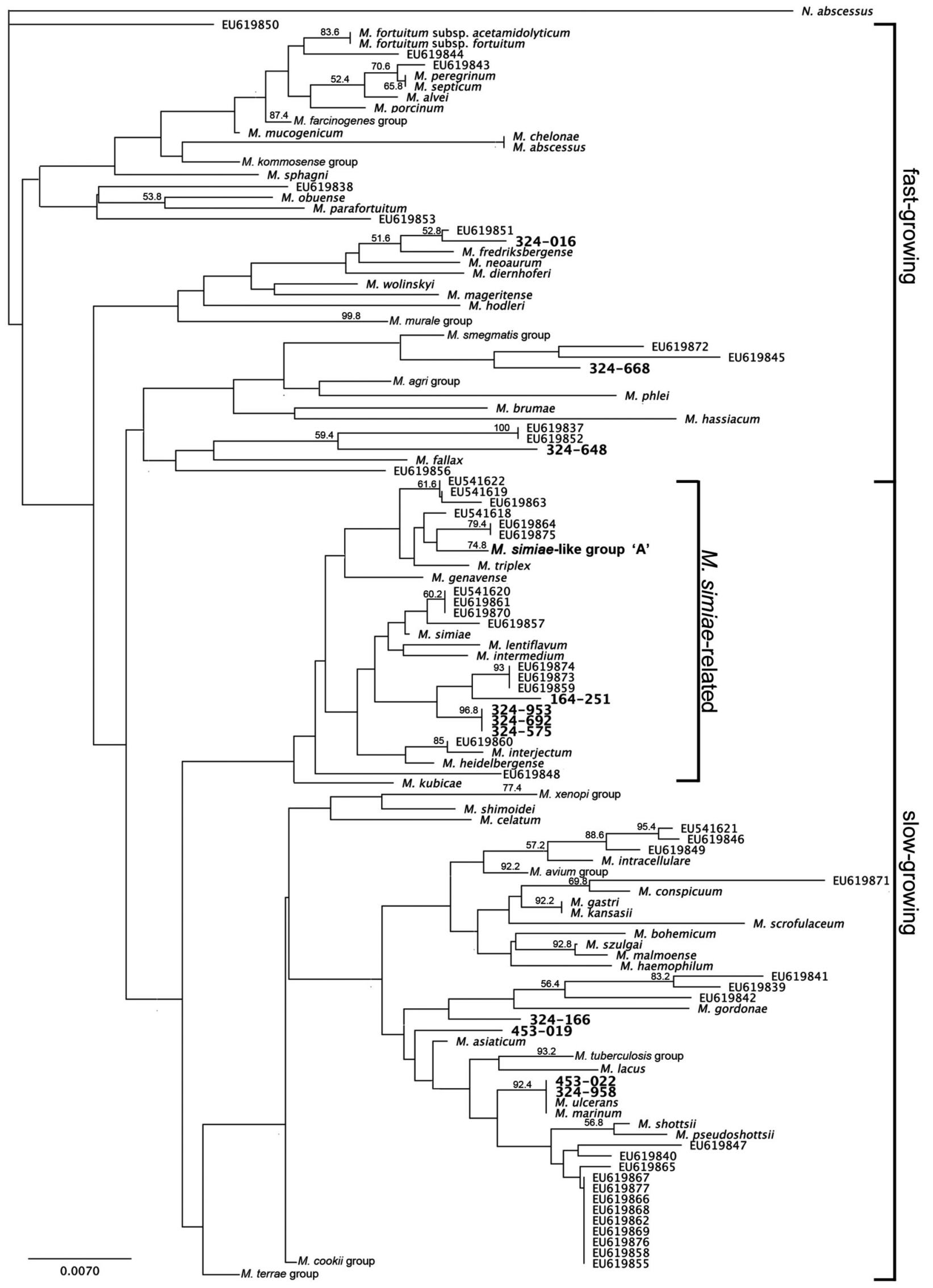


Geneious (Guindon \& Gascuel 2003). All phylogenies were run under the General Time-Reversible model estimating invariable sites and 4 substitution rate categories $(\mathrm{GTR}+\mathrm{I}+\mathrm{G})$. Five hundred boostrap replicates were performed for all trees.

Sequences at multiple loci (i.e. 16S rRNA, hsp65, rроB) from several mycobacteria isolated from Chesapeake Bay fishes other than Mycobacterium pseudoshottsii and M. shottsii have been deposited in GenBank (nos. EU619837 to EU619935), but, to our knowledge, an analysis of these sequences has not yet been published. Additional 16S rRNA gene sequences from isolates from Chesapeake Bay striped bass have also been deposited (nos. EU541619 to EU541622) and discussed briefly by Gauthier \& Rhodes (2009). Using the procedures detailed above, we generated an alignment and phylogenetic tree based on a $458 \mathrm{bp}$ fragment of the 16S rRNA gene common to photochromogenic isolates described in this report as well as to deposited sequences and $M$. pseudoshottsii and $M$. shottsii (Fig. 2). The Tamura-Nei model estimating invariable sites and rate variation $(\mathrm{TN}+\mathrm{I}+\mathrm{G})$ had the best likelihood score for this analysis as estimated by jModelTest; however, the GTR+I+G model also had support $(\triangle \mathrm{AIC}=6.8)$ and was used for consistency. Trees from both models had nearly identical topologies. Five hundred bootstrap replicates were performed for both analyses.

Sequences from 16S rRNA, hsp65 and rpoB genes have been deposited in GenBank under accession nos. HQ446163 to HQ446213.

\section{RESULTS}

Biochemical characteristics of photochromogens recovered from striped bass demonstrated heterogeneity between isolates and within groupings (Table 1). All isolates grew at room temperature and at $30^{\circ} \mathrm{C}$, and only 2 (324-688 and 324-016) were capable of growth at $37^{\circ} \mathrm{C}$. One isolate in the study, $324-016$, was characterized phenotypically as a fast-growing mycobacterium (Runyon Type IV), forming visible colonies on agar in less than $7 \mathrm{~d}$.
The global phylogenetic tree for Mycobacterium spp., including data from photochromogens in the present study (Fig. 1), was consistent with that previously reported for a global phylogeny that also included the sod gene and a longer rрoB fragment (Devulder et al. 2005). Slow-growing and fast-growing mycobacteria were well separated in monophyletic clades; however, the previously reported grouping (Devulder et al. 2005) of the fast-growing $M$. fallax and $M$. brumae within the slow-growing clade was not observed in the present study. Greater than $50 \%$ bootstrap support was present for $56.4 \%$ of nodes, and bootstrap support for important groupings of mycobacteria, such as the slow growers, was similar to that previously reported (Devulder et al. 2005). The 16S rRNA gene-based phylogeny, including study isolates as well as deposited sequences from Chesapeake Bay fish isolates, was also consistent with previously published work (Rogall et al. 1990, Tortoli 2003, Devulder et al. 2005) in terms of both topology and bootstrap support.

Two of the 17 photochromogenic isolates analyzed in the present study, 324-016 and 324-668, grouped genetically with the fast-growing mycobacteria in the global and 16S phylogenies (Figs. 1 \& 2). Isolate 324016 was grouped with $M$. frederiksbergense and $M$. neoaurum in global and 16S rRNA gene trees, and additionally with Mycobacterium sp. strain FL04-58-70A (EU619851) in the 16S rRNA gene phylogeny including deposited sequences from Chesapeake Bay isolates (Fig. 2). Sequence identity with strain FL04-58-70A was $98.8 \%$. Isolate $324-016$ was recovered from a striped bass in moderately high density $\left(6.3 \times 10^{4} \mathrm{~g}^{-1}\right)$, and in association with a non-pigmented Mycobacterium spp. Minor granulomatous inflammation was noted in the spleen of this fish, as were acid-fast bacteria (Table 2). Isolate 324-668 was grouped with $M$. moriokaense in the global tree, although with no $(<50 \%)$ bootstrap support. The closest BLAST pairwise similarities to the $16 \mathrm{~S}$ rRNA gene of isolate 324-668 were from Mycobacterium sp. A14N (GenBank no. AB251601) and 'Mycobacteriaceae bacterium MI-6.3 U19', (FN550143), at $99.4 \%$ and $99.1 \%$, respectively. The closest pairwise similarity of the 16S rRNA gene with a named species was with $M$. moriokaense strain CIP 105393

Fig. 2. Mycobacterium spp. Maximum likelihood analysis of $16 \mathrm{~S}$ rRNA gene fragment (458 bp) including variable sites A and B (Tortoli 2003). Sequences used are as for Fig. 1, with the addition of deposited 16S rRNA gene sequences obtained from Mycobacterium spp. derived from Chesapeake Bay fishes including M. shottsii (AY005147) and M. pseudoshottsii (AY570988). Bootstrap proportions and scale are as for Fig. 1. Certain clades are collapsed for clarity: $M$. farcinogenes group = $M$. farcinogenes, $M$. senegalense; $M$. kommosense group = M. kommosense, $M$. aichiense, $M$. rhodesiae; $M$. murale group = $M$. murale, $M$. tokaiense; $M$. smegmatis group = M. smegmatis, $M$. goodii, $M$. madagascariense, $M$. elephantis, $M$. pulveris, $M$. moriokaense, $M$. thermoresistibile, $M$. flavescens; $M$. agri group $=M$. agri, $M$. doricum, $M$. austroafricanum, $M$. novocastrense; $M$. simiae-like Group ' $\mathrm{A}$ ' = study isolates as described in text; $M$. xenopi group $=M$. xenopi, $M$. heckeshornense, $M$. botniense $M$. avium group = M. avium subspp. avium, silvaticum and paratuberculosis; $M$. tuberculosis group $=M$. tuberculosis, $M$. bovis BCG, $M$. bovis CIP, M. bovis subsp. caprae, $M$. africanum, M. microti; $M$. cookii group = M. cookii, $M$. branderi; $M$. terrae group = $M$. terrae, $M$. hiberniae, M. nonchromogenicum, M. triviale 


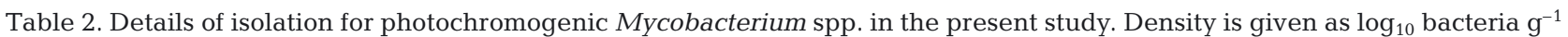
spleen (see Rhodes et al. 2004). Acid-fast co-isolates from the same spleen sample are given as: Sc $=$ scotochromogenic isolate, $M p=M$. pseudoshottsii, $M s=M$. shottsii, NP = non-pigmented isolate ${ }^{*}$ co-isolate numerically dominant in the sample. The collection location is given as Rappahannock River (RR), with distance upriver in kilometres as measured by the central channel (RR $0=$ river mouth), or mainstem Stn $1\left(38.3068^{\circ} \mathrm{N}, 76.2838^{\circ} \mathrm{W}\right)$ or $\operatorname{Stn} 12\left(37.6483^{\circ} \mathrm{N}, 76.2742^{\circ} \mathrm{W}\right)$. Fish age was determined by either otolith or scale analysis. 'Disease severity' is explained in 'Materials and methods'; the presence (+) or absence (-) of acidfast bacteria (AF) is given in parentheses

\begin{tabular}{|c|c|c|c|c|c|c|c|c|}
\hline Isolate name & $\begin{array}{l}\text { Density } \\
\left(\log _{10}\right)\end{array}$ & $\begin{array}{l}\text { Co-isolate } \\
\text { (acid-fast) }\end{array}$ & $\begin{array}{c}\text { Fish collection } \\
\text { date }(\mathrm{mm} / \mathrm{dd} / \mathrm{yy})\end{array}$ & $\begin{array}{l}\text { Collection } \\
\text { location }\end{array}$ & $\begin{array}{l}\text { Fish age } \\
(y r)\end{array}$ & $\begin{array}{l}\text { Fork length } \\
\quad(\mathrm{mm})\end{array}$ & Sex & $\begin{array}{c}\text { Disease severity } \\
(\mathrm{AF}+/-)\end{array}$ \\
\hline \multicolumn{9}{|c|}{ M. simiae-related Group A } \\
\hline $324-844$ & 2.0 & $\mathrm{Sc}$ & $4 / 2 / 07$ & RR 72 & 5 & 520 & $\mathrm{M}$ & $0(-)$ \\
\hline $324-569$ & 1.7 & None & $11 / 14 / 05$ & Mainstem (12) & 2 & 319 & $\mathrm{~F}$ & $0(-)$ \\
\hline $324-137$ & 1.8 & $\mathrm{Sc}$ & $10 / 16 / 06$ & RR 72 & 4 & 494 & M & $0(-)$ \\
\hline $324-815$ & 2.5 & $\mathrm{Sc}$ & $4 / 2 / 07$ & RR 72 & 5 & 479 & M & $1(+)$ \\
\hline 324-635 & 2.1 & None & $4 / 6 / 06$ & RR 72 & 2 & 380 & $\mathrm{~F}$ & $1(-)$ \\
\hline $324-669$ & 1.7 & None & $4 / 11 / 10$ & RR 72 & 3 & 432 & $\mathrm{M}$ & $1(-)$ \\
\hline \multicolumn{9}{|c|}{ M. simiae-related Group B } \\
\hline $164-251$ & 2.2 & None & $3 / 21 / 05$ & Mainstem (1) & 2 & 217 & $\mathrm{M}$ & $1(+)$ \\
\hline $324-575$ & 3.0 & $M p$ & $11 / 14 / 05$ & Mainstem (12) & 2 & 299 & $\mathrm{~F}$ & $1(+)$ \\
\hline $324-692$ & 1.6 & None & $4 / 10 / 06$ & RR 72 & 4 & 531 & M & $1(+)$ \\
\hline $324-953$ & 3.2 & Ms & $4 / 5 / 07$ & RR 72 & 5 & 562 & $\mathrm{M}$ & $1(-)$ \\
\hline \multicolumn{9}{|l|}{ Fast-growing } \\
\hline $324-016$ & 4.8 & NP & $10 / 12 / 06$ & RR 72 & 3 & 423 & M & $1(+)$ \\
\hline $324-668$ & 3.4 & $\mathrm{Sc}_{1} M s^{*}$ & $4 / 10 / 06$ & RR 72 & 4 & 516 & M & $1(+)$ \\
\hline \multicolumn{9}{|l|}{ M. marinum } \\
\hline $453-022$ & 8.2 & None & $5 / 8 / 07$ & RR 0 & 3 & 476 & M & $2(+)$ \\
\hline $324-958$ & 5.8 & None & $4 / 5 / 07$ & RR 72 & 4 & 468 & $\mathrm{M}$ & $2(+)$ \\
\hline \multicolumn{9}{|c|}{ Misc. slow-growing } \\
\hline $324-166$ & 6.5 & $M s^{*}$ & $10 / 20 / 06$ & RR 0 & 4 & 541 & $\mathrm{M}$ & $2(+)$ \\
\hline 453-019 & 5.6 & None & $5 / 8 / 07$ & RR 0 & 5 & 567 & M & $0(-)$ \\
\hline $324-648$ & 2.1 & None & $4 / 6 / 06$ & RR 72 & 2 & 385 & $\mathrm{M}$ & $1(-)$ \\
\hline
\end{tabular}

(AY859686), at 98.2\%. Isolate 324-668 was capable of growth at $37^{\circ} \mathrm{C}$ and was the only photochromogenic study isolate to possess the cytosine insertion at Escherichia coli position 184 characteristic of thermotolerant fast-growing mycobacteria (Tortoli 2003). 16S rRNA variable region $B$ displayed a typical insertion-free (short-helix) sequence. Two deposited 16S rRNA gene sequences from Chesapeake Bay fishes grouped with isolate 324-668, although without bootstrap support (Fig. 2). These sequences, from Mycobacterium spp. FL04-42-151SpA (EU619845) and FL04-42-158A (EU619872) demonstrated 96.5\% and 98.8\% identity with 324-668, respectively. Isolate 324-668 was present at a density of $2.5 \times 10^{3} \mathrm{~g}^{-1}$ splenic tissue in a polyinfection with $M$. shottsii and a scotochromogenic Mycobacterium (Table 2). Minor granulomatous inflammation and acid-fast bacteria were present.

A majority (10/17) of photochromogenic study isolates clustered in the global phylogeny with the 'Mycobacterium simiae-related' group described by Tortoli (2003). These isolates formed 2 groups in the global phylogeny, with high (>85\%) bootstrap support for the proximal node including all group isolates. We refer here to these groups as M. simiae-related groups 'A' and 'B' (Fig. 1).
Within Group A, isolates 324-635 and 324-669 were $100 \%$ similar at all loci, and 324-815 and 324-569 differed by 1 position in the rpoB gene. All $M$. simiae-related Group A isolates shared 100\% similarity at the 16S rRNA gene locus. $M$. simiae-related Group B isolates, consisting of 164-251, 324-953, 324-575 and 324-692, differed from each other and from Group A isolates at all loci. All 10 isolates in M. simiae-related Groups A and B had an uninserted helix 18 in the 16S rRNA gene, but variable region A, particularly E. coli positions 189 to 195, was consistent within groups. Group A isolates had the sequence $5^{\prime}$-ACG AGG C-3' at this position, which is consistent with $M$. stomatepiae (HM022202) and ' $M$. sherrisii' (AY353699), as well as deposited sequences from 3 Chesapeake Bay isolates, i.e. Mycobacterium spp. strains L30 (EU541618), FL04-60-11A (EU619875) and FL04-60-260B (EU619864). With the exception of 164251 (5'-ATT TAG C-3'), M. simiae-related Group B isolates had the sequence $5^{\prime}$-ACT TAG C-3' at this position. This sequence at this position appears to be unique among the mycobacteria, with the exception of a deposited sequence from an uncultured soil isolate (GU172203; uncultured bacterium clone DSM-R31). Densities of M. simiae-related Group A and B isolates 
recovered from striped bass spleens were generally low, ranging from $4.0 \times 10^{1}$ to $1.6 \times 10^{3} \mathrm{~g}^{-1}$ spleen. Some $(5 / 10)$ isolates were present in monoinfections, and polyinfections with $M$. pseudoshottsii and M. shottsii as well as uncharacterized scotochromogens were observed. In the case of monoinfections, granulomatous inflammation was observed in 4/5 instances; however, disease severity was minor. Acid-fast bacteria were observed in 2/5 monoinfections (Table 2 ). In addition to the 10 study isolates, 15 deposited sequences from Mycobacterium spp. isolated from Chesapeake Bay fishes were grouped with the $M$. simiae-related mycobacteria in the 16S rRNA phylogeny including these sequences (Fig. 2).

Two of the 17 study isolates, 453-022 and 324-958, were $100 \%$ similar to Mycobacterium marinum ATCC 927 at all 3 loci tested. Isolates 453-022 and 324-958 are separated from $M$. marinum in the global alignment due to a $2 \mathrm{bp}$ difference from the $M$. marinum sequence deposited by Devulder et al. (2005), which was from strain CIP104528. Both isolates were phenotypically consistent with $M$. marinum (Lévy-Frébault \& Portaels 1992), but differed in pyrazinamidase activity. In both cases, these isolates were recovered as a monoinfection from striped bass spleen, and were present in high densities of $1.6 \times 10^{8} \mathrm{~g}^{-1}$ and $6.3 \times 10^{5} \mathrm{~g}^{-1}$ spleen, respectively. Moderate granulomatous inflammation and large numbers of acid-fast bacteria were present in spleens from both fish (Table 2).

The phylogenetic placement of isolates 324-166 and 453-019 was ambiguous. Both were definitively placed within the slow-growing mycobacteria by a 12 bp insertion in helix 18 (Tortoli 2003). These isolates clustered together with high bootstrap support in the global phylogeny (Fig. 1); however, 16S rRNA gene phylogeny, including other Chesapeake Bay isolates, placed the former with $M$. gordonae and the latter in a group with members of the $M$. marinum clade and the $M$. tuberculosis clade. BLAST analysis was not particularly helpful in resolving the position of these isolates, as the highest similarity returned was $98.9 \%$ to the $16 \mathrm{~S}$ rRNA gene of M. tuberculosis H37Ra (CP000611) for isolate 453-019 and $98.9 \%$ to the $16 \mathrm{~S}$ rRNA gene of $M$. gordonae for isolate 324-166. The 16S rRNA phylogeny including Chesapeake Bay-derived sequences grouped isolate 324-166 with the 16S rRNA gene for the striped bass isolates FL04-5-253F (EU619842), FL04-23-N47C (EU619839), and FL04-60-213LA (EU619841), although without bootstrap support (Fig. 2). Isolate 453019 was a sole, high-density $\left(4.0 \times 10^{5} \mathrm{~g}^{-1}\right.$ spleen $)$ isolate, and no granulomatous inflammation or acid-fast bacteria were noted. Isolate 324-166 was found at high density $\left(3.2 \times 10^{6} \mathrm{~g}^{-1}\right.$ spleen $)$ in a polyinfection with high-density $M$. shottsii, and moderate granulomatous inflammation with acid-fast bacteria was present (Table 2).
Isolate 324-648 did not group closely with other study isolates, but was placed with $M$. terrae in the global phylogeny. Sequence identity with $M$. terrae strain ATCC 15755 (DQ058407) was 97.1\%, although higher identity $(98.7 \%)$ was observed with a sequence reported for $M$. terrae strain M64 (GQ184162). Sequence identity of $100 \%$ was noted with the $16 \mathrm{~S}$ rRNA gene of Mycobacterium sp. GN-9188 (FJ497240), a human clinical isolate from Greece. Isolate 324-648 was obtained as a low-density, sole isolate $\left(1.3 \times 10^{2} \mathrm{~g}^{-1}\right.$ spleen), and minor granulomatous inflammation was noted with no acid-fast bacteria observed. Coloration of this isolate was unique, as it was pale pink, whereas all other isolates were pale to golden yellow. Placement of this isolate via the 16S rRNA phylogeny, including deposited Chesapeake Bay-derived sequences, was problematic in that the isolate was placed with the fast-growing $M$. fallax as well as Mycobacterium spp. strains 06FL-1-2A (EU619852) and 06FL-1-5B-1 (EU619837) (Fig. 2). While M. fallax has an uninserted short helix in the $16 \mathrm{~S}$ variable region B, isolate 324-648, as well as Mycobacterium spp. strains 06FL-1-2A and 06FL-1-5B-1, have insertions in this region, clearly marking them genetically as slowgrowing mycobacteria. Interestingly, while $M$. fallax is included in the same clade as the slow-growing $M$. terrae when isolate 324-648 is included in the 16S rRNA phylogeny excluding additional Chesapeake Bay isolates, M. fallax and $M$. terrae are placed in separate clades when isolate $324-648$ is omitted.

\section{DISCUSSION}

Two isolates in the present study clustered genetically with fast-growing mycobacteria, but were not closely similar to either $M$. chelonae or $M$. fortuitum. Isolate 324-016 was clustered with $M$. frederiksbergense and related organisms by global and individual gene phylogenies. Sequence identity with $M$. frederiksbergense was $99.5 \%$ at the $16 \mathrm{~S}$ rRNA locus, and higher identity (99.8\%) was seen to Mycobacterium sp. IK1-18P (AB461006), isolated from soybeans. This grouping of mycobacteria contains the soil isolates $M$. frederiksbergense (Willumsen et al. 2001), M. neoaurum, $M$. hodleri and $M$. diernhoferi (Tsukamura et al. 1983), of which $M$. neoaurum has been implicated in human disease (Davison et al. 1988, Morimoto et al. 2007) and has been described from Chinook salmon Oncorhynchus tshawytscha, although this identification was made from phenotypic characters alone (Backman et al. 1990). Members of this group of mycobacteria can degrade polycyclic hydrocarbons (Kleespies et al. 1996, Willumsen et al. 2001) and are thus considered to be highly adapted to the environ- 
mental niche, although human infections with $M$. neoaurum and striped bass infection with isolate 324016 in the present study indicate that, like many other 'environmental' mycobacteria, members of this group are capable of opportunistic infection. The phylogenetic position of the second isolate in the fast-growing group, 324-668, was not well resolved. The closest 16S rRNA gene matches were to environmental isolates or environmental DNA, while the most closely similar recognized species was $M$. moriokaense, an isolate from human and soil sources (Tsukamura et al. 1986). This isolate did demonstrate affinity with the thermotolerant fast-growing mycobacteria, based on a characteristic cytosine insertion in helix 10 of the $16 \mathrm{~S}$ rRNA.

The numerically dominant group of photochromogenic mycobacteria in the present study was clustered with the 'Mycobacterium simiae-related' group described by Tortoli (2003), including $M$. lentiflavum, M. simiae, M. triplex, M. genavense, M. palustre, $M$. interjectum, $M$. intermedium and related species. While considered the most homogeneous grouping in Mycobacterium spp. based on the 16S rRNA sequence (Tortoli 2003), this group demonstrates considerable diversity in terms of phenotype and reservoirs. While several species in this group are known only from human clinical samples, others (e.g. M. palustre, $M$. genavense and $M$. simiae) have been detected in water and non-human animals (Schroder et al. 1992, Portaels et al. 1996, Torkko et al. 2002, Conger et al. 2004), and M. lentiflavum-like 16S rRNA sequences have been obtained from soil by PCR (Mendum et al. 2000). Mycobacteria belonging to the $M$. simiae-related group have also been described from a number of other finfishes (Herbst et al. 2001, Levi et al. 2003, Whipps et al. 2003, Poort et al. 2006). Whereas the diversity of $M$. marinum-group organisms infecting poikilotherms has received much attention in recent years (Ranger et al. 2006, Yip et al. 2007), the diversity of $M$. simiae-related mycobacteria is considerably less well studied.

With the exceptions of $M$. marinum isolates 324-958 and 453-022, none of the isolates described in the present study was closer than $99.0 \%$ identical at any locus to previously deposited mycobacterial sequences from Chesapeake Bay isolates, further demonstrating the unrecognized diversity present among Mycobacterium isolates from this environment. Examination of the partial 16S rRNA gene phylogeny of all study isolates and deposited sequences, however, does demonstrate some interesting trends. Most notable is the large number of isolates in the $M$. simiae-related group, with 10 of 17 photochromogenic isolates from the present study and 15 of 45 previously deposited sequences. It is therefore apparent that fishes in Chesapeake Bay are capable of harbouring a large diversity of Mycobacterium spp. belonging to this taxonomic grouping, and that the prevalence and potential pathogenicity of these bacteria may be worthy of future study.

Isolates 324-016 and 324-668, which were genetically grouped with fast-growers in the present study, were grouped with 1 and 2 additional deposited sequences, respectively. In comparison, only 2 deposited sequences from Mycobacterium spp. strains FL04-68-5LA (EU619843) and FL04-58-32A (EU619844) were grouped closely with the classical fish pathogen $M$. fortuitum and none with $M$. chelonae/M. abscessus. This contrasts with most other reports of fast-growing mycobacterial infections in fishes, which typically implicate $M$. fortuitum or $M$. chelonae, instead involving mycobacteria from groups primarily associated with hydrocarbon degradation in contaminated soils.

Within study isolates genetically identified as slowgrowers, 3 in particular (324-166, 324-648 and 453019) were not well placed taxonomically, with inconsistent grouping and/or no bootstrap support at individual gene loci. All 3 isolates did, however, group with sequences from other Chesapeake Bay isolates (Fig. 2). It is worth noting that, of the 17 photochromogenic study isolates, only 4 (324-166 and 453-019, M. marinum isolates 453-022 and 324-958) were separated from another sequence derived from a Chesapeake Bay isolate by more than 1 node in the $16 \mathrm{~S}$ rRNA phylogeny, and only 453-019 was more than 2 nodes distant from a grouping of these sequences. This would seem to indicate that despite the great diversity of Mycobacterium spp. that infect Chesapeake Bay fishes, the major groupings to which these species and strains belong are beginning to be described.

It should be carefully noted that isolates described in the present study represent single isolations from individual animals, and consequently, no information is conveyed as to their prevalence and distribution. Further, while some isolates were obtained in monocultures, and granulomatous inflammation was present in some of these cases, this is not a fulfilment of Koch's postulates and little can be said about their pathogenicity or virulence. The ability of bacterial and parasitic agents other than Mycobacterium spp. to elicit granulomatous inflammation is well-known, and we do not assume here that all observed granulomata were due to Mycobacterium. This situation is further complicated in the case of polyinfections with known pathogens such as Mycobacterium shottsii. M. simiaegroup isolates, in particular, were typically found at low densities in the spleen and did not appear to be associated with severe pathology; however, whether they are capable of producing significant disease under conditions of host stress is unknown. 
Acknowledgements. Funding to D.T.G. and A.M.H. for multilocus sequence analysis was provided by the Old Dominion University Undergraduate Research Grant program. Isolates from the Rappahannock River, Virginia, were collected during projects funded by NOAA (Chesapeake Bay Office) and Virginia Marine Resources Commission through the WallopBreaux-funded striped bass monitoring and assessment program. We thank Dr. J. Hoenig, P. Sadler and D. Gonzales for assistance with these projects. Samples from the mainstem Chesapeake Bay were collected using the Chesapeake Bay Multispecies Monitoring and Assessment Program (ChesMMAP) and funding from United States Geologic Survey Cooperative Research Agreement 02ERAG0071. We thank Dr. R. Latour, C. Bonzek and J. Gartland for use of the ChesMMAP platform and Drs. C. Ottinger and F. Panek for their participation in the USGS agreement. The authors also thank M. Korngiebel-Rosique and M. Colasanto for laboratory assistance.

\section{LITERATURE CITED}

Ausubel FM, Brent R, Kingston RE, Moore DD, Seidman JG, Smith JA, Struhl K (eds) (1999) Short protocols in molecular biology, Vol 1. John Wiley, Hoboken, NJ

Backman S, Ferguson HW, Prescott JF, Wilcock BP (1990) Progressive panophthalmitis in a chinook salmon, Oncorhynchus tshawytscha (Walbaum): a case report. J Fish Dis 13:345-353

Blackwood KS, He C, Gunton J, Turenne CY, Wolfe J, Kabani AM (2000) Evaluation of recA sequences for identification of Mycobacterium spp. J Clin Microbiol 38:2846-2852

Cloud JL, Meyer JJ, Pounder JI, Jost KC Jr, Sweeney A, Carroll KC, Woods GL (2006) Mycobacterium arupense sp. nov., a non-chromogenic bacterium isolated from clinical specimens. Int J Syst Evol Microbiol 56:1413-1418

Conger NG, O'Connell RJ, Laurel VL, Olivier KN and others (2004) Mycobacterium simiae outbreak associated with a hospital water supply. Infect Control Hosp Epidemiol 25: 1050-1055

Cousins DV, Bastida R, Cataldi A, Quse V and others (2003) Tuberculosis in seals caused by a novel member of the Mycobacterium tuberculosis complex: Mycobacterium pinnipedii sp. nov. Int J Syst Evol Microbiol 53:1305-1314

Davison MB, McCormack JG, Blacklock ZM, Dawson DJ, Tilse $\mathrm{MH}$, Crimmins FB (1988) Bacteremia caused by Mycobacterium neoaurum. J Clin Microbiol 26:762-764

> de Mendonca-Lima L, Picardeau M, Raynaud C, Rauzier J and others (2001) Erp, an extracellular protein family specific to mycobacteria. Microbiology 147:2315-2320

Devulder G, de Montclos MP, Flandrois JP (2005) A multigene approach to phylogenetic analysis using the genus Mycobacterium as a model. Int J Syst Evol Microbiol 55: 293-302

$>$ Drummond AJ, Ashton B, Cheung M, Heled J and others (2010) Geneious v5.1. Available at www.geneious.com

Euzéby JP (1997) List of bacterial names with standing in nomenclature: a folder available on the internet. Int J Syst Bacteriol 47:590-592

Gauthier DT, Rhodes MW (2009) Mycobacteriosis in fishes: a review. Vet J 180:33-47

> Gauthier DT, Latour RJ, Heisey DM, Bonzek CF, Gartland J, Burge E, Vogelbein WK (2008a) Mycobacteriosis-associated mortality in wild striped bass (Morone saxatilis) from Chesapeake Bay, USA. Ecol Appl 18:1718-1727

Gauthier DT, Vogelbein WK, Rhodes MW, Reece K (2008b) Nested PCR assay for detection of Mycobacterium shottsii and Mycobacterium pseudoshottsii in striped bass (Morone saxatilis). J Aquat Anim Health 20:192-201

Guindon S, Gascuel O (2003) A simple, fast, and accurate algorithm to estimate large phylogenies by maximum likelihood. Syst Biol 52:696-704

Hennessee CT, Seo JS, Alvarez AM, Li QX (2009) Polycyclic aromatic hydrocarbon-degrading species isolated from Hawaiian soils: Mycobacterium crocinum sp. nov., Mycobacterium pallens sp. nov., Mycobacterium rutilum sp. nov., Mycobacterium rufum sp. nov. and Mycobacterium aromaticivorans sp. nov. Int J Syst Evol Microbiol 59: 378-387

- Herbst LH, Costa SF, Weiss LM, Johnson LK and others (2001) Granulomatous skin lesions in moray eels caused by a novel mycobacterium species related to Mycobacterium triplex. Infect Immun 69:4639-4646

Kasai H, Ezaki T, Harayama S (2000) Differentiation of phylogenetically related slowly growing mycobacteria by their gyrB sequences. J Clin Microbiol 38:301-308

> Kim BJ, Lee SH, Lyu MA, Kim SJ and others (1999) Identification of mycobacterial species by comparative sequence analysis of the RNA polymerase gene (rpoB). J Clin Microbiol 37:1714-1720

Kim BJ, Hong SK, Lee KH, Yun YJ and others (2004) Differential identification of Mycobacterium tuberculosis complex and nontuberculous mycobacteria by duplex PCR assay using the RNA polymerase gene $(r p o B)$. J Clin Microbiol 42:1308-1312

> Kleespies M, Kroppenstedt RM, Rainey FA, Webb LE, Stackebrandt E (1996) Mycobacterium hodleri sp. nov., a new member of the fast-growing mycobacteria capable of degrading polycyclic aromatic hydrocarbons. Int J Syst Bacteriol 46:683-687

> Levi MH, Bartell J, Gandolfo L, Smole SC and others (2003) Characterization of Mycobacterium montefiorense sp. nov., a novel pathogenic mycobacterium from moray eels that is related to Mycobacterium triplex. J Clin Microbiol 41:2147-2152

> Lévy-Frébault VV, Portaels F (1992) Proposed minimal standards for the genus Mycobacterium and for description of new slowly growing Mycobacterium species. Int J Syst Bacteriol 42:315-323

Mendum TA, Chilima BZ, Hirsch PR (2000) The PCR amplification of non-tuberculous mycobacterial 16S rRNA sequences from soil. FEMS Microbiol Lett 185:189-192

- Morimoto Y, Chan ED, Heifets L, Routes JM (2007) Pulmonary infection with Mycobacterium neoaurum identified by $16 \mathrm{~S}$ ribosomal DNA sequence. J Infect 54: e227-e231

Ottinger CA, Brown JJ, Densmore C, Starliper CE and others (2007) Mycobacterial infections in striped bass from Delaware Bay. J Aquat Anim Health 19:99-108

> Poort MJ, Whipps CM, Watral VG, Font WF, Kent ML (2006) Molecular characterization of a Mycobacterium species in non-native poeciliids in Hawaii using DNA sequences. J Fish Dis 29:181-185

Portaels F, Realini L, Bauwens L, Hirschel B, Meyers WM, De Meurichy W (1996) Mycobacteriosis caused by Mycobacterium genavense in birds kept in a zoo: 11-year survey. J Clin Microbiol 94:319-323

> Posada D (2008) jModelTest: phylogenetic model averaging. Mol Biol Evol 25:1253-1256

Pourahmad F, Cervellione F, Thompson KD, Taggart JB, Adams A, Richards RH (2008) Mycobacterium stomatepiae sp. nov., a slowly growing, non-chromogenic species isolated from fish. Int J Syst Evol Microbiol 58: 2821-2827 
Ranger BS, Mahrous EA, Mosi L, Adusumilli S and others (2006) Globally distributed mycobacterial fish pathogens produce a novel plasmid-encoded toxic macrolide, mycolactone F. Infect Immun 74:6037-6045

Rhodes MW, Kator $\mathrm{H}$, Kotob S, van Berkum $\mathrm{P}$ and others (2001) A unique Mycobacterium species isolated from an epizootic of striped bass (Morone saxatilis). Emerg Infect Dis $7: 1-3$

Rhodes MW, Kator H, Kotob S, van Berkum P and others (2003) Mycobacterium shottsii sp. nov., a slowly growing species isolated from Chesapeake Bay striped bass. Int J Syst Evol Microbiol 53:421-424

Rhodes MW, Kator H, Kaattari I, Gauthier D, Vogelbein W, Ottinger CA (2004) Isolation and characterization of mycobacteria from striped bass Morone saxatilis from the Chesapeake Bay. Dis Aquat Org 61:41-51

Rhodes MW, Kator H, McNabb A, Deshayes C and others (2005) Mycobacterium pseudoshottsii sp. nov., a slowly growing chromogenic species isolated from Chesapeake Bay striped bass (Morone saxatilis). Int J Syst Evol Microbiol 55:1139-1147

Ringuet H, Akoua-Koffi C, Honore S, Varnerot A and others (1999) hsp65 sequencing for identification of rapidly growing mycobacteria. J Clin Microbiol 37:852-857

Rogall T, Wolters J, Flohr T, Böttger EC (1990) Towards a phylogeny and definition of species at the molecular level within the genus Mycobacterium. Int J Syst Bacteriol 40: 323-330

Roth A, Fischer M, Hamid ME, Michalke S, Ludwig W, Mauch $\mathrm{H}$ (1998) Differentiation of phylogenetically related slowly growing mycobacteria based on 16S-23S rRNA gene internal transcribed spacer sequences. J Clin Microbiol 36:139-147

Runyon EH (1959) Anonymous mycobacteria in pulmonary disease. Med Clin North Am 43:273-290

Schinsky MF, Morey RE, Steigerwalt AG, Douglas MP and others (2004) Taxonomic variation in the Mycobacterium fortuitum third biovariant complex: description of $\mathrm{Myco-}$ bacterium boenickei sp. nov., Mycobacterium houstonense sp. nov., Mycobacterium neworleansense sp. nov., and Mycobacterium brisbanense sp. nov. and recognition of Mycobacterium porcinum from human clinical isolates. Int J Syst Evol Microbiol 54:1653-1667

Schroder KH, Kazda J, Muller K, Muller HJ (1992) Isolation of Mycobacterium simiae from the environment. Zentralbl Bakteriol 277:561-564

Shojaei H, Magee J, Freeman R, Yates M, Horadagoda N, Goodfellow M (2000) Mycobacterium elephantis sp. nov., a rapidly growing non-chromogenic Mycobacterium isolated from an elephant. Int J Syst Evol Microbiol 50: 1817-1819

Stine CB, Kane AS, Baya AM (2010) Mycobacteria isolated

Editorial responsibility: David Bruno,

Aberdeen, UK from Chesapeake Bay fish. J Fish Dis 33:39-46

Stinear TP, Jenkin GA, Johnson PDR, Davies JK (2000) Comparative genetic analysis of Mycobacterium ulcerans and Mycobacterium marinum reveals evidence of recent divergence. J Bacteriol 182:6322-6330

Telenti A, Marchesi F, Balz M, Bally F, Böttger E, Bodmer T (1993) Rapid identification of mycobacteria to the species level by polymerase chain reaction and restriction enzyme analysis. J Clin Microbiol 31:175-178

Torkko P, Suomalainen S, Iivanainen E, Suutari M, Tortoli E, Paulin L, Katila M (2000) Mycobacterium xenopi and related organisms isolated from stream waters in Finland and description of Mycobacterium botniense sp. nov. Int J Syst Evol Microbiol 50:283-289

Torkko P, Suomalainen S, Iivanainen E, Tortoli E and others (2002) Mycobacterium palustre sp. nov., a potentially pathogenic, slowly growing mycobacterium isolated from clinical and veterinary specimens and from Finnish stream waters. Int J Syst Evol Microbiol 52:1519-1525

> Tortoli E (2003) Impact of genotypic studies on mycobacterial taxonomy: The new mycobacteria of the 1990s. Clin Microbiol Rev 16:319-354

- Tsukamura M, van der Meulen HJ, Grabow WOK (1983) Numerical taxonomy of rapidly growing, scotochromogenic mycobacteria of the Mycobacterium parafortuitum complex: Mycobacterium austroafricanum sp. nov. and Mycobacterium diernhoferi sp. nov., nom. rev. Int J Syst Bacteriol 33:460-469

Tsukamura M, Yano I, Imaeda T (1986) Mycobacterium moriokaense sp. nov., a rapidly growing, nonphotochromogenic mycobacterium. Int J Syst Bacteriol 36:333-338

> Whipps CM, Watral VG, Kent ML (2003) Characterization of a Mycobacterium sp. in rockfish, Sebastes alutus (Gilbert) and Sebastes reedi (Westrheim \& Tsuyuki), using rDNA sequences. J Fish Dis 26:241-245

Whipps CM, Butler WR, Pourahmad F, Watral V, Kent ML (2007) Molecular systematics support the revival of Mycobacterium salmoniphilum (ex Ross 1960) sp. nov., nom. rev., a species closely related to Mycobacterium chelonae. Int J Syst Evol Microbiol 57:2525-2531

- Willumsen P, Karlson U, Stackebrandt E, Kroppenstedt R (2001) Mycobacterium frederiksbergense sp. nov., a novel polycyclic aromatic hydrocarbon-degrading Mycobacterium species. Int J Syst Evol Microbiol 51:1715-1722

Yip MJ, Porter JL, Fyfe JAM, Lavender CJ and others (2007) Evolution of Mycobacterium ulcerans and other mycolactone-producing mycobacteria from a common $\mathrm{Myco}-$ bacterium marinum progenitor. J Bacteriol 189: 2021-2029

> Zolg JW, Philippi-Schulz S (1994) The superoxide dismutase gene, a target for detection and identification of mycobacteria by PCR. J Clin Microbiol 32:2801-2812

Submitted: November 2, 2010; Accepted: February 25, 2011 Proofs received from author(s): May 26, 2011 